\title{
NURSING CONTINUING EDUCATION IN THE UNITED STATES
}

\section{A PAPER DELIVERED AT THE SYMPOSIUM "TOTAL HEALTH IS BOAN IN MIDWIFERY", JOHANAESBURG, MARCH 1881.}

\author{
ROBERT B. ROCK, JR., MP, MPA. \\ Professional Relations Department, Johnson and Johnson Baby Products Company, U.S.A.
}

\section{OPSOMMING}

Met die omskrywing van die Amerikaanse verpleegstersvereniging se definisie van voortgesette onderwys as uitgangspunt en gepaard met agtergrondinligting oor die basiese akkrediteringseenheid, gee die stuk 'n algemene oorsig van die ontwikkeling van die begrip van voortgesette onderwys in die dekade sewentig en skets dit die struktuur van sy administrasie - met kommentaar oor onderrigtegnieke, die vakbestek wat aangebied word en die benaderings tot evaluasie. Daarna gee dit 'n beskouing oor die belangrikste vrae en probleme en sluit af met opmerkings oor hoe voortgesette onderwys die verpleegster-vroedvrou raak.

T HE discussion of nursing continuing education in the United States is approached by a consideration of the following aspects:

Definition and Background

Evolution of the Concept

Administration of the Process

Teaching Techniques

Range of Subjects

Evaluation of the Program

Issues and Problems:

Mandatory vs. Voluntary Participation

Control of the Accreditation Process

Responsibility for Participation Program Cost/Availability

\section{DEFINITION AND BACK- GROUND}

Most of us would probably agree that the term continuing education includes some form of learning activity after a basic educational program but because it has been subject to various interpretations a definition from the organization most broadly associated with nursing continuing education in the U.S. would be appropriate.* During 1974, the American Nurses' Association (ANA), in it's statement on Continuing Education in Nursing said:

* In Sourh A trica consinuing education is reparded as all postregistration education, whether formal or informal. (E.d)
Continuing education in nursing consists of s!'stemaric learning experiences designed to enlarge the knowledge and skills of nurses. As distinct from educarion toward an ac'ademic degree or preparing as a beginning professional practirioner, continuing professional educational activities have more specific content applicable to the individual's immediate goals; are generally of shorter duration; are sponsored by colleges, universities, health agencies and professional organizations; and may' be conducted in a variety of settings. 1

This statement resulted from a resolution passed in 1974 by the ANA House of Delegates which resolved to establish a system of accreditation of continuing education programs in nursing. This was further supported in the same year by a statement by the National League for Nursing (NLN), in effect the accreditor of college and university programs, which established guidelines for the development of continuing education porgrams in nursing. The League's position statement, which outlined its role in continuing education, included a comment to the effect that contmining education is a personal evaluarive educational experience, objectively planned for individual grow'th and enrichment of and atritudes and skills beyond the basic preparation for a profession or occupation. The manner in which continuing education is oblained and the merhod of documenting it, while important, are secondary to the goal, which is to assure the continued development of competence of nursing personnel at all levels of practice and education. ${ }^{2}$

Based on the full role statement, the League went on to establish guidelines which focused on four factors for program development: assessment, planning, implementation and evaluation. The detailed subheadings are available from the League's statement and the guidelines are probably most notable for reference to use of the continuing education unit (CEU) within the Implementation section. The CEU, developed by a national task force made up of representatives of 34 organizations and agencies, is defined as Ten contact hours of parricipation in an organized iontimuing education experience under responsible leadership, capable direc'tion and qualified instruction.' CEU's are not used for programs carrying academic credit or diplomas, in-setvice learning, orientation programs or short-term programs casually related to upgrading. 
It's principal benefit stems from it's general acceptance as a standard unit for organized educational offerings, and the emphasis is on the word organized.

\section{EVOLUTION OF THE CONCEPT}

Actually, continuing education for nurses in the United States had it's early beginnings around the turn of the century, mainly to make up for the poor quality of education in many programs, where students were used almost entirely to meet service needs... Institutes and workshops $b_{1}$ the professional organization gained some momentum in the 1920's and are still a major source of continuing education. Refresher courses for inactive nurses were most prevalent in times of major nursing shortages, such as during World War II and the 1950's and 1960's. Federal funding under the Nursing Training Act in 1964 provided funding for short term courses, and institutions of higher education took a renewed interest in providing continuing education, an interest that had dwindled through lack of funds and prepared facult:. Other federal funding for Regional Medical Programs also resulted in nursing workshops. When these funds began to vanish during the Nixon administration, many colleges found it impossible to continue full programs. Others, seeing both the need and the trend, established institution-funded continuing education programs. ${ }^{4}$ This led to greater emphasis on inservice education.

By the turn of the decade, momentum had picked up to the point where Prof. Malcolm Knowles of the University of NC, well known for his writings in the field, said: I believe that in the '70's continuing education will become an integral element of all the professions in general, but of nursing in particular. The creation of a new role. that of Continuing Education Specialist, will assure that every professional practitioner is engaging in a process of continuing self-development. ${ }^{5}$ While the role of the continuing education specialist has most certainly evolved. the author believes that the best most practitioners - together with Prof. Knowles - would say about assurance of continuing self-develop- ment is, given the state of the art, that we have made a commendable beginning.

A good part of that commendable beginning can be associated with the ANA's development of an administrative structure. As has already been noted, the year 1974 was kind of a benchmark, with publication of ANA's resolution and NLN's supporting position statement. It was further highlighted by ANA's publication of Standards for Continuing Education in Nursing which were directed to three principal areas: program, resources and evaluation and included twenty-one criteria. Although pertinent in their entirety, perhaps point No. 4 under Program addressed the central core of requirements. It stated:

Continuing Education programs are designed to assist nursing personnel to:

- acquire and update knowledge and skills

- prepare for reentry into practice

- make a transition from one area of practice to another

acquire greater depth of knowledge and skill in one particular area of nursing

- enhance professional attitudes and values

implement concepts of change both within the individual's ow'n practice and throughout the health care delivery sistem

- assume responsibility for personal and professional development

encourage the improvement of the ability of other health care personnel to meet the specific needs of the public served b. the health agenc.

- promote and support innovation and creativity in health services.

The points under Evaluation are not comparably explicit. They were notable for their lack of reference to How' To.

\section{ADMINISTRATION OF THE PROCESS}

By 1975 a great deal had been said, written and actually accomplished in terms of putting programs in place. This included a lot of ideas on record keeping and administration. Everything was essentially voluntary and bordering on the comparably chaotic. During the summer of that year the
ANA published a series of pamphlets on Accreditation of Continuing Education in Nursing in which the association did an admirable job of outlining all the nitty-gritty subjects on continuing education in nursing about which you needed information and didn't know whom to ask.

The structure of the accreditation process is illustrated in Diagram 1 and it's function is described by Popiel ${ }^{6}$ as follows:

Organizationally, the model is headed by the Commission on Nursing Education which designates line authority to the National Accreditation Board (NAB). Under $N A B$ are three Regional Accrediting Committees (commonly referred to as $R A C s$ ); eastern, central and western. Originally, there were five RACs, but economic considerations changed this.

In addition to the RACs, NAB also governs a National Review Committee, which is responsible for accreditation of non-degree granting programs preparing nurses for extended roles.

\section{How the Model Works}

The model encompasses local, state, regional, and national levels and functions in two ways. First, it identifies criteria for accrediting other agencies and associations as approval bodies of CE offerings. For example, if a state nurses' association applies for and is granted accreditation as an approval body it may in turn approve an individual provider within the state. This provider can then offer programs that are "ANAapproved".

Secondly, the model also identifies criteria for the approval of individual continuing education offerings and programs. This is the usual route for independent or commercial providers who present programs in more than one state. Obtaining ANA approval of their programs often, though not always, eliminates the need to apply to each individual state.

The mechanism emphasizes selfregulation and collaboration between all levels of the ANA, other national nursing organizations, health agencies and organizations, and providers who sponsor continuing education activities for nurses. 


\section{DIAGRAM 1 ACCREDITATION OF CONTINUING EDUCATION IN NURSING}

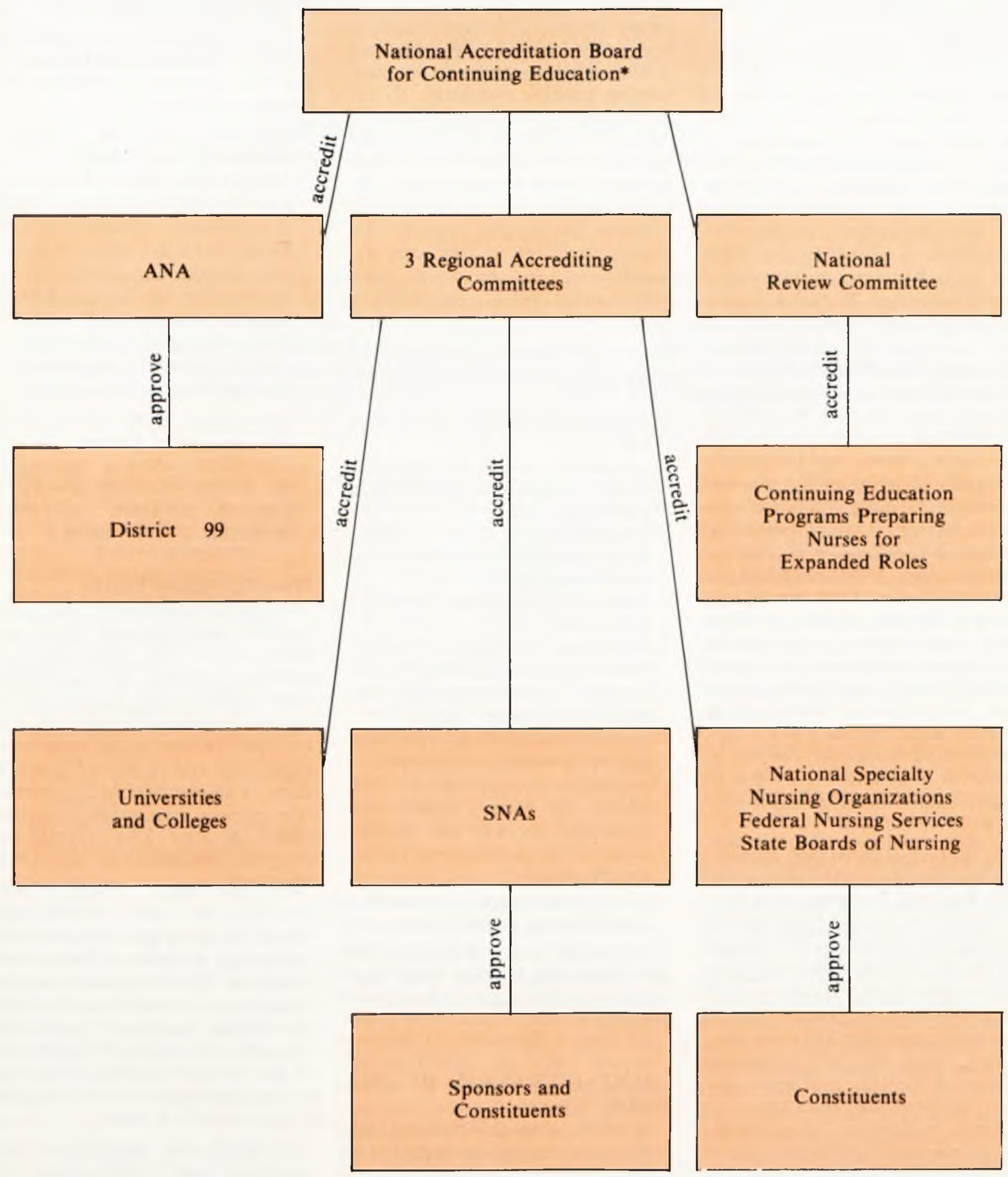

${ }^{*}$ A monitoring group will be established to evaluate the effectiveness of the Natic aal Accreditation Board for a minimum of five years. 
Overall authority and responsibility for reviewing and revising the accreditation and approval criteria reside in the National Accreditation Board for Continuing Education.

The three RACs grant accreditation to universities and colleges, national nursing organizations, state boards of nursing, state nurses associations, national specialty nursing organizations, and federal nursing services. The committees also approve offerings of independent providers and commercial organizations.

A separate National Review Committee, which is also governed by NAB, reviews applications and accredits the non-degree programs for the expanded role.

Only state boards of nursing, state nurses' associations, national specialty organizations and federal nursing services are eligible to apply for accreditation and as approvers of the offerings of their constituents. Universities and colleges, and national nursing organizations receive only accreditation. Commercial companies may apply for a pproval of their programs/offerings but not for accreditation. As a matter of fact, Johnson \& Johnson Companies have developed and received approval for a number of CE offerings - for example. The Post-Operative Wound Care Program and The Hospital Product Evaluation Workshop.

\section{What is the Difference Between Accreditation and Approval?}

Many providers of continuing education as well as nurses are confused about the difference between accreditation and approval of $\mathrm{CE}$ programs and offerings. Definitions of the two words, as published in the booklet Accreditation of Continuing Education in Nursing, begin to help clear the confusion.

ACCREDITATION - The public recognition $b_{1}$ the professional association that the CE program (the overall program, not an individual offering) of the organization being reviewed meets certain standards as determined through evaluations (self and review' committee) hased on predetermined (riteria.

APPROVAL - The review and acceptance bl an accredited body. of the total program or individual offerings of a sponsor or constituent hased on predetermined criteria.

Not all providers of continuing education are eligible for accreditation but may have their offerings approved by an accredited state nurses association or state board of nursing. The federal nursing services and national specialty organizations may approve only the offerings of their constituents. All the organizations who approve CE offerings must have an approval mechanism which meets the criteria set forth by NAB.

\section{Purposes of Accreditation}

The essential purpose of the accreditation process is to provide a professional nursing judgement regarding the quality of the $\mathrm{CE}$ offerings and/or programs. Through the national accreditation process, the professional association seeks to promote the standards for $\mathrm{CE}$ in nursing at the national, state, and local levels. The process also encourages sponsors to persistently improve the quality of their offerings.

As can be readily seen, the accreditation process is complex; it is also awkward, time-consuming and expensive. On the other hand, it works, and will probably improve with time, experience and improved computer techniques. The ANA is found to be tough but fair.

\section{TEACHING TECHNIQUES}

Another aspect of nursing continuing education in the United States which is interesting stems from several well established trends - the segmentation of speciality groups within nursing resulting in an increased number of nursing speciality organizations; the knowledge communications explosion - which makes more knowledge more available to the expanded specialities; the shift in teaching concepts from pedagogy to adragogy which gears continuing education to adults as learners?; - all of which have truly exercised the vehicles for teaching techniques and because of competition for attention and the need for variety, have brought the whole gamut into play.

Two issues of a publication called CME Marketing Memo highlighted
Alternatives to the Lecture Method: This included techniques for offerings through colloquy, committee, demonstration, field trips and groups. These were derived from a guidebook for CE providers developed for the University of Florida which lists outlines, definitions, uses, advantages and problems for the various methods. For example the outline on common group methods listed eight types: forum, group discussion, interview, panel, quiet meeting, seminar, speech and symposium. The immediate tendency is to anticipate overlaps but this is quickly clarified in the outline for definition, uses, advantages and problems which go with each of the previously mentioned types. The outline headings for Forum were, for example:

\section{Definition}

15-60 minule period of open discussion that is carried on among members of the group.

\section{Uses -}

Clarify specifics; encourage contributions; thorough discussion; flexible interaction; identify needs. Advantages

Suited for in-depth discussion; produces new considerations.

\section{Disadvantages}

Lack of skillful moderators; lack of time; audience reluctance; inappropriate facult!; unpredictable.

This type of analytical approach to teaching techniques is, of necessity, increasingly called into play and uses a broader range of vehicles for improved techniques in an increasingly competitive market for CE offerings.

\section{RANGE OF SUBJECTS}

For the most part the same trends which have exercised the use of expanded teaching techniques and vehicles have also stimulated a very broad range of subject offerings. The real extent of this range cannot be conveyed but a quick insight is provided into the scope offered by the University of Pennsylvania School of Nursing Center for Continuing Education during the academic year Fall 1980/Spring 1981:

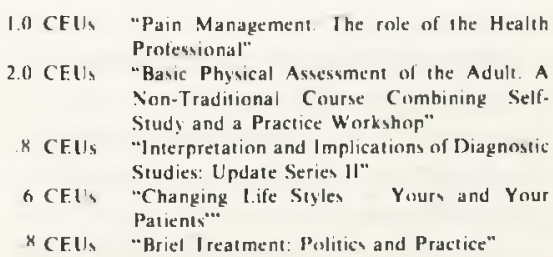
Protessional"

2.0 CEU/s "Basic Physical Assessment of the Adult. A Son-Traditional Course Combining SelfStudy and a Practice Workshop"

\& CEU/s "Interpretation and Implications of Diagnostic Studies: Update Series II"

h CEl's "Changing life Styles Yours and Your Patients."

*CFUl, "Briel Ireatment: Politica and Practice" 


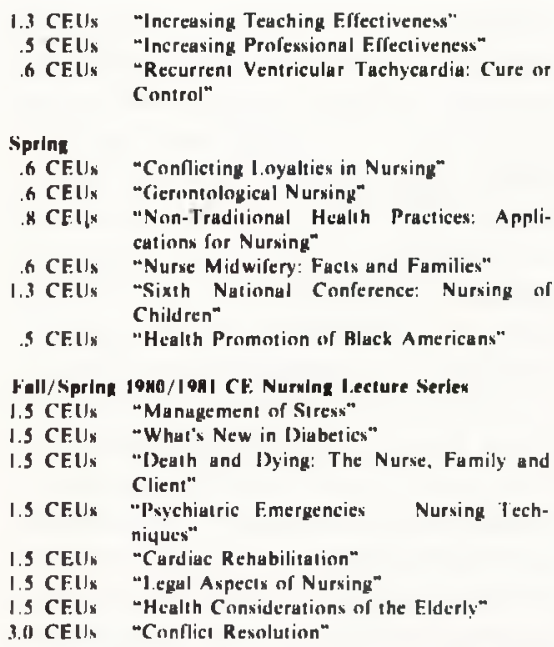

This collection of twenty-two offerings over a period of nine months, averaging better than two per month, is pretty broad and diverse fare and the University of Pennsylvania is by no means unique. This can be multiplied by a factor of several thousand approved providers and you would probably be in the range of the $\mathrm{CE}$ offerings available nationwide. Unfortunately, despite the marvels of computer high technology, the figure cannot really be corroborated because there is no program clearing house mechanism. However, it is a good sized number, and now the reader can begin to understand why continuing education programs have become highly competitive for both nursing time and money: why continuing education has become a big business and why nurses are becoming increasingly selective.

\section{EVALUATION}

With all this information available to change minds - figuratively and literally - what about evaluation of these programs? An effective technique, process or instrument all wrapped up, does not exist. Popiel points out in Nursing and the Process of Continuing Ealucarion that evaluarion is of deep concern to all continuing education persomnel and will continue to he." The following are suggested evaluations that can be done:

evaluation of growth of partici, pants;

self-evaluation of participants; evaluation of courses;

evaluation of overall program; evaluation of effectiveness of resource persons:

evaluation of outcomes of courses as they affect the participants' performance on the job: evaluation of improvement of patient care because of the new knowledge skills and insights acquired at a course.

Obviously number seven is the name-of-the-game payoff for which we are looking. Even when specific behavioural objectives are written so that each one can be evaluated in terms of outcomes, performance difference levels are difficult to measure.

Perhaps the four most accepted criteria are:

satisfaction (Happiness Index);

What did participants learn? (PrePost Test);

transfer of knowledge (Pre-Post-

Test: Hospital Data);

effect on the system (Hospital

Epidemiological Data)

The first wo levels produce measurahle feedhack which is comparatively easy to assess. It is the last iw' from which it is difficult to initiate and oblain reliable data. Results and significant proof that the parricipant's knowledge gained has been transferred to practice or that there has been an effect on the sistem are evaluation problems that have let 10 be solved. 10 However, the author shares Popiel's point of view that evaluation is a necessity and that the search for scientific evaluation of continuing education programs must continue.

\section{ISSUES AND PROBLEMS}

Based on what has been said about nursing continuing education administration, teaching techniques, range of subjects and evaluation of programs, it is not surprising, since it is a subject very close to the hearts, minds and pocketbooks of a comparatively large number of Americans. that it may have stimulated a few issues and problems. Most of the issues, all of which represent problems, are inextricably interrelated and revolve around a central concern for professional competency. The principal issues include (not necessarily in order of importance): mandatory versus voluntary participation; control of the accreditation process: responsibility for participation and program cost/availability.

\section{Mandatory versus voluntary participation}

The concept of special knowledge, expertise and competency is inherent in the definition of professionalism and while health care professionals in general, and nursing in particular, has held self-regulatory accountability and competency inherent in a license to practice, the public has doubted the responsiveness of some professionals in voluntarily meeting their public trust obligations. Proof demanded of the medical profession became federally mandated through the passage of legislation which required peer review through Professional Standards Review Organization (PSRO). Despite efforts by the ANA, nurses were not included in the PSRO legislation and in an effort to demonstrate accountability in 1974 the ANA House of Delegates publicly went on record in favor of mandatory continuing education as a condition of relicensure. The intent was to demonstrate competency in nursing practice. Mandatory as opposed to voluntary continuing education has become one of the more controversial issues in nursing

Since 1974 a number of states have passed laws requiring continuing education programs for relicensure. At one point nurses in as many as fourteen states were faced with mandatory continuing education requirements, although as of the end of 1980 this number has dropped to eleven. The case for mandatory continuing education stems in large measure from the fact that although licensure for nurses fills a social need which is outwardly supported by the competence inherent in the profession, in actual practice the environment in which mursing is practiced is ofien not one that is conducive to encouraging comtinuing educarion, so that there is no imperus 10 seck new educational experiences .... The real issue. then, is mandaonly relicensure, and implicit within the concept of relicensture is the threat that some murses mal have their licensess wirhdrawn. " Writing in the Journal of the American Hospital Association, Myra Levine, an Associate Professor at the University of Illinois College of Nursing says: // is time to hegin a lough move lowards homest professional practice. Mandatory relicensure is a social need, and a professional murse appreciates a 
social need . . It is only through mandatory relicensure and a commitment to excellence that the nursing profession will realise the true dimensions of professional practice. ${ }^{12}$ Interestingly, Prof. Levine is far from a voice in the wilderness. A relatively recent survey conducted by Nursing '78 among a random sample of 900 subscribers had a 61 percent response in favour of mandatory continuing education, 30 percent were opposed and 9 percent were undecided.

However, the decade of the 80 's may show us the other side of the coin, with a reversal of the trend toward mandatory continuing education. One reason is the lack of definitive research findings correlating continuing education with nursing practice ... if there is no proof of improved practice, through mandatory $\mathrm{CE}$ to demonstrate competence in practice it becomes irrational. ${ }^{13}$ Writing in AORN Journal, Gwen Dodge. AORN's Assistant Director of Education points up another reason, stating One of the facts of political life is the subile and not so subtle influence exercised by vested interests. At least one of these groups, the hospital industry, is likely. to contribute to the decline of mandatory CEfor relicensure... State hospital associations generally oppose the requirement hecause, among other reasons, the believe mandatory. $C E$ has increased hospital operating expenses without proven cost savings". Ms. Dodge continues, "The final blow for the movement will come when the first license is denied for failure to meet $C E$ requirements. The ensuing legal action will be precedent setring and, if as likell. the iudgement goes in favor of the licensee, every state mandating $C E$ will abolish the requirement with all due haste". 14 Actually, a voluntary program has been set up which does allow maximum freedom for nurses to set their individual education goals and recognises their achievement of them. Called CEARP (Continuing Education Approval and Recognition Program), the system works like this: the National Accreditation Board of the American Nurses' Association certifies state nursing associations as continuing education providers and approval bodies. This ANA certification provides national recognition of contact hours earned by registered nursés who attend continuing education activities approved or offered by the state nursing associations.

Nurses who attain a designated number of contact hours within a specified time are aw'arded cerrificates of recognition by the state associations. Their achievement is recorded and publicized. and in many cases their employers are notified. Also. most states with mandatory continuing education permit nurses moving into the state to transfer credits earned elsewhere under CEARP to meet their licensure requirements.

Solne states with mandatory programs have voluntary ones as well. One such state is Colorado, which recognizes under CEARP those nurses who ac'cumulate 60) contact hours in two years, three times the mandalory requirement. Thus, the state hoard is attempting to assure competency under its mandatory' program; the state association is attempring to encourage excellence under CEA RP. ${ }^{15}$

However, regardless of the outcome of the controversy for mandatory versus voluntary continuing education, what is not controversial is the responsibility of the nurse, as a professional practitioner, 10 maintain competence in whatever area of practice is heing engaged in: clinical. adininistrative or other. ${ }^{16}$

\section{Control of the accreditation process}

Another major issue involves control of the accreditation process. As has already been discussed, the ANA has set up a working process for accreditation. We also noted that the National League for Nursing (NLN) issued statements of support. Implicit in those statements was the fact that NLN would continue to accredit conlinuing education nursing programs in university or college sellings. The original concerns about the duplicative accreditation role of each organization have not heen resolved. ${ }^{17}$ A further complicating factor is that a number of the nursing speciality organisations have their own accreditation procedures which do not lall within the ANA framework, and other specialities control both credentialing and the content of continuing education programs for their respective members. An example of the former is the organization of Pediatric Nurse Practitioners (NAPNAP); an example of the latter is the Nurses' Association of the American College of Obstetrics and Gynecology (NAACOG). The ANA accreditation structure was discussed previously; Diagram 2 shows how NAACOG ties into it

NAACOG sought and was granted initial accreditation from the ANA/ NAB in 1976. It is currently accredited as both approver and provider of continuing education through to 1983, at which point it will submit for re-accreditation approval for another four year period. The NAACOG Fact Sheet on Accreditation points out: Tw'o NAACOG national committees are responsible for revien' of NAACOG Programs and derermining the quality of content as w'ell as designating the contact hour credit to be given. The Committee on Education review's all continuing education programming which is subsequently offered on a national level. This includes NAACOG continuing education courses and national meetings. The Program Review' Commitlee is responsible for reviening and approving or denling contact hour credit to programs developed by NAACOG districts. ${ }^{\text {in }}$

What has just been discussed only deals with the tip of the complexity iceberg. However, it should indicate that there is something less than a standardized approach to handling continuing education. This situation could probably be vastly alleviated if the nursing profession could agree on the establishment of a proposed centre for credentialing, the study for which has recently been completed. This study addresses all aspects of rredentialing of institutions and individuals in the occupation of nursing. including accreditation, certification. licensing degree designation and orher forms. ${ }^{19}$ The study proposal is currently under serious consideration by most of the organizations within the nursing profession in the United States. If it can do what it proposes to do for the credentialing structure in the United States - the current structure is illustrated in Diagram 3 and the proposed structure in Diagram 4 - just think what that magnitude of change might do for the structure of continuing education, and it could start with centralized record keeping for CEU credits 


\section{DIAGRAM 2}

\section{NAACOG ACCREDITATION STRUCTURE}

by the

American Nurses' Association National Accreditation Board

American Nurses' Association/National Accreditation Board I

North Central Regional Accrediting Committee

NAACOG

APPROVER

Program Review Committee approved

(Developed by district)
PRÖVIDER

Committee on Education approved

(Developed by Department of Education)

\section{Responsibility for Participation}

The next major issue involves responsibility for participation in continuing education programs. When all is said and done, this probably centers primarily on the individual. It could be argued that responsibility for providing and assuring continuing education for members resides in the professional organization, which makes continuing education participation a condition of membership. This is actually the case, and has worked well, for some state medical societies in the United States. However, given past positions and current trends, it seems more likely that it will continue to be incumbent on the individual nurse, regardless of membership in professional organizations, to assume individual responsibility for participation in continuing education. After completion of the basic program it is up to the individual to maintain a level of current competency commensurate with her professional commitment and public expectations. In the recent climate of malpractice suits, such a demonstrable commitment to competency can also serve as an insurance policy.

\section{Program Cost and Availability}

The final major issue under consideration is program cost and availability. Who should bear the cost of the nurse's continuing education has been the subject of some heated discussion. Formalized programs in continuing education are offered as in-service education in places of em- plovment, through conferences, workshops, institutes and other program meetings of professional or other health organizations, or in continuing education programs offered b. colleges and universities. Only inservice education is alwals free. The other programs frequenily' charge at least a token fee of some kind, even for members because the cost of providing quality programs is high. Some courses, which may extend over a period of dal's or months. could run into hundreds of dollars hovever, the average fee appears to be closer to $\$ 25.00$.

The professional nurse should expect to bear part of the cost. There are some nho feel that because the employers ultimately benefit from the employee's improved performance they should provide some support as partial or full tuition palments, sabbaticals or short-term leaves. On the other hand, hospitals and like institutions often maintain that these additional costs must be passed on unfairly to the patient and that the have the right to expect competent practitioners. ${ }^{20}$ Both hospitals and universities point out that qualifying for ANA approval is an expensive, time-consuming process.

Another cost/availability factor is that while there is almost a plethora of offerings, they are concentrated in urban areas which makes participation by rural nurses more timeconsuming and expensive. It also raises the question of formal/classroom versus informal home-study and programmed learning. Coupled with these are the considerations of quality versus accessability.

The cost impact cuts two ways and more recently it has been felt as much by the universities and big association providers as by participants. Government and grant funding which has done much to facilitate big organisation providers has recently been less available, which has had the impact of cutting back on both the quality and availability of offerings. To some extent, this gap has been filled by commercial providers of which there are two varieties. The first is represented by manufacturers of health care products whose offerings are largely oriented to mutual interest this might be called industry continuing education. The other might be called the continuing education industry - commercial companies who have capitalized on mandatory continuing education with program offerings for profit. This is a logical development in a free enterprise society and, because theirs have had to be quality offerings which qualify for CEUs in order to survive, they have provided serious competition for the academic and association programs.

With so many programs from which to choose sophisticated nurses have become increasingly selective with regard to cost, quality and accessability. Gloria Hochman in an article titled Continuing Education: How Can You Make the Most of It? in Nursing '78 comments: How' to pick the best program for you? Whether continuing education is voluntary or mandarory in lour state, lou have the burden of selecting the quality. programs most appropriate to you. Doing so effectively requires skill, sophistication and aggressive consumerism that many nurses are just beginning 10 cultivate. ${ }^{21}$ And I suspect the realistic nurse may ask herself: "and what are my deficiencies?"

\section{NURSE-MIDWIFERY AND NURSING CONTINUING EDU- CATION IN THE UNITED STATES}

As a final consideration in our review (If continuing education in nursing in the United States a brief insight nto how continuing education affects American nurse-midwives is given, through the kindness of $\mathrm{Ms}$. Fay Lebowitz, Administrative Direc- 


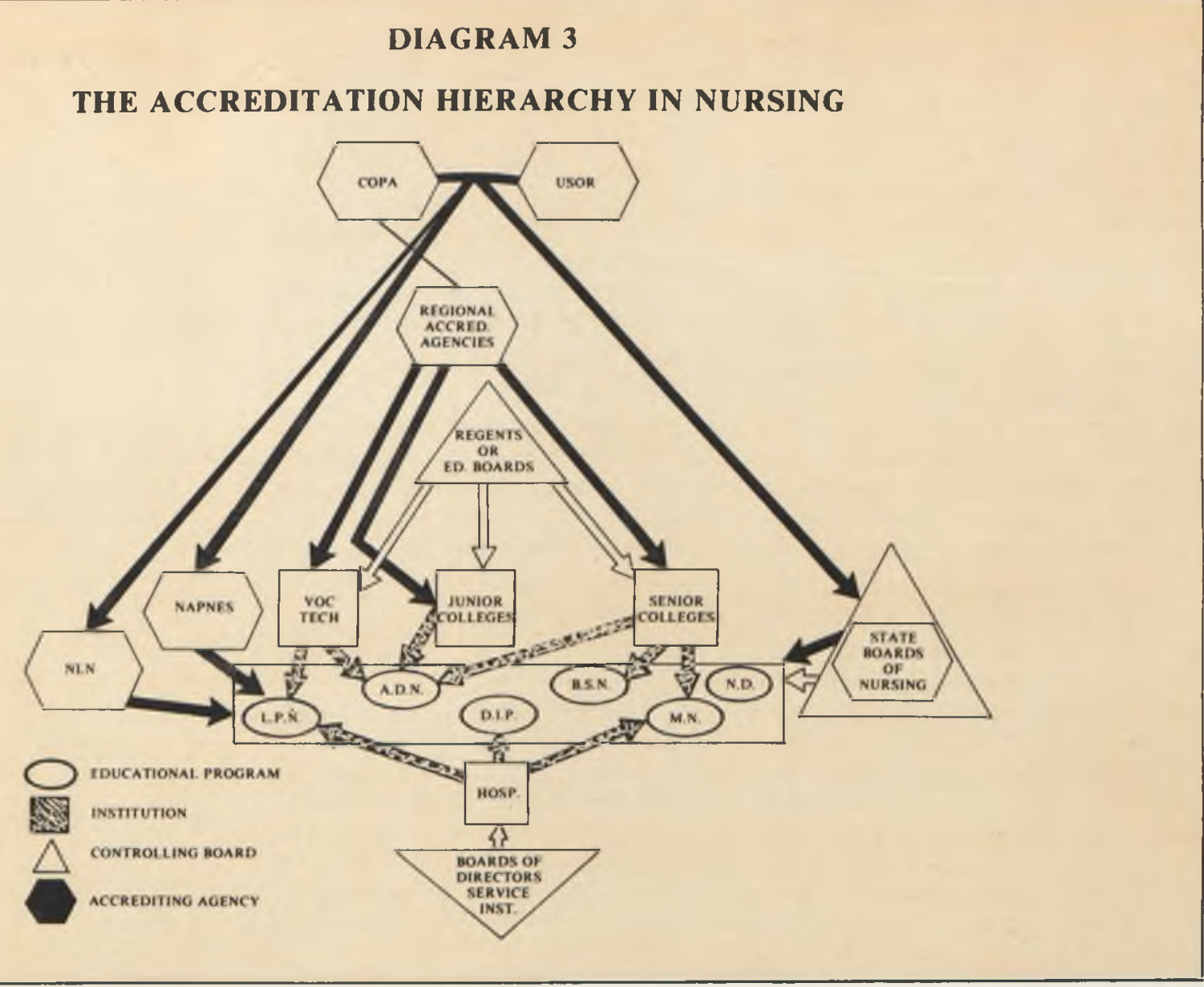

DIAGRAM 4

\section{SIMPLIFIED DIAGRAM OF A POSSIBLE STRUCTURE FOR A NURSING CREDENTIALING CENTRE}

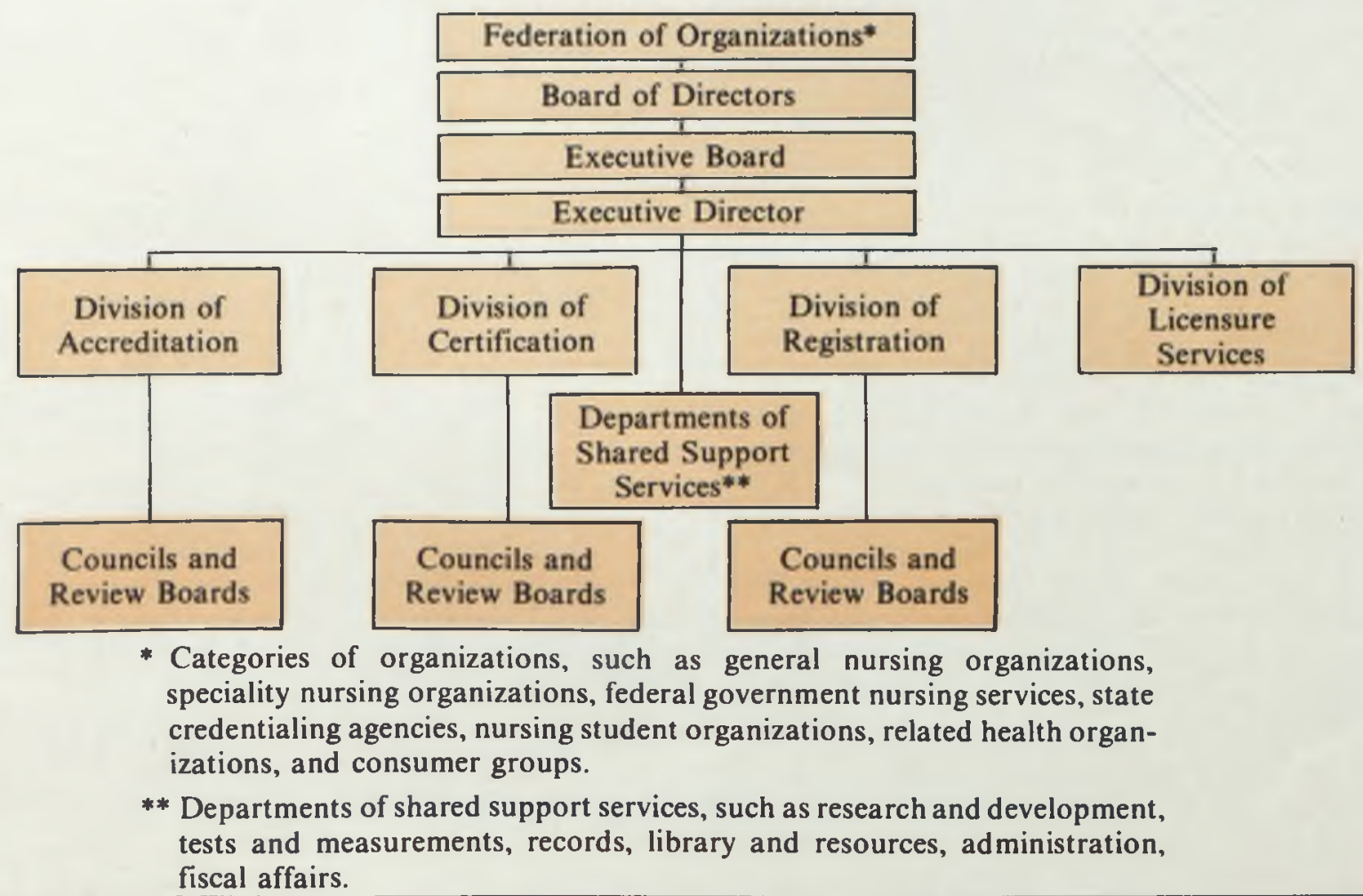


tor of the American College of Nurse Midwives and Mary Brucher, CNMW, Chairperson for the College's Committee on Continuing Education. It is both interesting and frustrating to contemplate the calch-22 situation which prevails in states where there is mandatory continuing education.

In the United States a nursemidwife has to be registered as a nurse in at least one state, presumably the state in which she starts her practice. If she moves her practice to another state, it is necessary to transfer her registration. Since there is reciprocity among all the states for the transfer of registration, this transfer can be accomplished through the payment of a fee to the State Board of Nursing. However, the same reciprocity does not necessarily apply to the transfer of continuing education credit. Although for the present nurses and nurse midwives participate in continuing education, programs, for the most part, on a voluntary basis, there are eleven states where continuing education is mandatory - i.e. where it is essential to have a certain number of continuing education contact hours each year for license renewal.

There are two broad types of continuing education agencies: those which are not for profit - represented generally by academic institutions, hospitals and professional organizations; and those which are for profit such as commercial companies like NURSECO and ASPEN, or like such state agencies as those which exist in Florida and California. In connection with the latter, for example, continuing education credit obtained in California is not necessarily transferable to Florida. While the nurse-midwife moving from California to Florida can transfer her license because of nationwide reciprocity, she cannot qualify for her license in Florida because of the catch 22 situation that she must first meet all of Florida's continuing education requirements. This is both time consuming and expensive and tends to slow down the rate of transfers of nurse-midwives between states with mandatory continuing education. However, for the hardy souls determined to transfer, there is a small silver lining in that states with mandatory continuing education requirements offer more continuing education programs because there is a tailor-made market.

\section{CONCLUSION}

This concludes the observations about nursing continuing education in the United States. If the impression has been given that a lot is happening, that is correct; if it has been implied that a lot still needs to happen that, too, is correct. And, if you in South Africa are planning to expand your program for nursing continuing education, it might be said - somewhat brashly - that you are commended to further study of the United States process, just as long as you do it with an eye to simplification.

\section{References}

American Nurses Association Sratumen on Comminumg Education in Nursing. American Nurses Association. Kansas City MO. 1974

Walsh. M.E. The Role of NI.N in Continuing Education in Nursing. Journal of Continuing Education in Nursing. Vol. 3 No. 3. pp. 44-4

Ibid

4. Kelly. Lucie S. Dimensions of Professtonal Nursing Fourth Fdition. Macmillan. New York. 1981. p. 649 Popicl. Elda S.-Ed Nursing and the Process of Comunuing Education. Mosby. St. Louis. 1977, 2nd Ed p. 15 Popicl. Elda $S$ Approval Mechanism for Continum Education in Nursing ( $E$ Fosis. November December. 1979. pp. 6-7. 1979. $\mathrm{Pp}$. 6-7.

Knapp, Steven R. Fd (ME Marhering Meme. Vol II. No. 11 . (November). No. 12 (December). Chicago. 1980 Op Cit. pp. 171-173

10. Ibid

11. Levine, Myra E. Does Continuing Education Improve Nursing Practice? Jourmal of the American Howpiral A. weriarum. Vol 52. No 1. 1978. pp. 1.38-140.

2. Ibid.

13. Dodge Gwen H I.egislators l.ook Askance at Mandatory CE. AORN Jinurnal. Vol 31. No. 6. May 1980. pp. 1080lo9l.

5. Hochman. Gloria Continuing Education: How Can You Make the Most of it? Nursing 78. December 1978 p. 87. Kelly, Lucie 5 Dimensions of Professional Nursing. Macmillan New York. 1981.4th Ed.p. 650 Op. Cit. p. 962 .

17. Nurses Associaiton American Coilege OB GYN Fa"? Sheet: A'AACOG Accredication hy American. Nurses Asssuiation National Accreditation Brard. NAACOG Chicago. June. 1979.

19. Styles. M.M. et al. The Stud of Credentialing In Nursing: A New Approach. American Nurse Association. Kansas City. MO. March 1979. p. iii.

20. Kelly. Lucie S. Dimensioms of Professional Nursing Macmillan New York. 1981 4ih Ed. p. 649.

Hachman. Gloria Continuing Education: You Can You Make the Best of It" Nirsing 78. December 1978. p. 86.
Bibliozraphy

Alexander, Carol AOR N's Role in Aproval of CE in Nursing. AORN Jinurnal. Vol. 23. No, 6. May 1976. pp. 959-964.

2. ANA - Accreditation of Continuing Education in Nursing

State Nurses Association

National Specialty Associations

Federal Nursing Services

State Boards of Nursing

(Developed by the Ad HOC Committee on Accreditation of Continuing Education, Members of the Executive Committee on Continuing Education. and Members of the Commission on Nursing Education. 19741976). American Nurses Association. Kansas City 1975.

3NA Accrediration of Cimminuing Elucation Pruprans Accrediration of Cominning Eclucation Programs Preparing Norses for Expanted Rorles.

Amercan Nurses Associalion Kansas Cily. 1975.

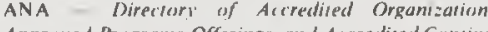
Approved Programs Offerings. and Accredired ConimuIng Education Cersificale Programs Preparing Nuris Prachirioners. ANA. Kansas Cily. March 1980.

ANA Standards for Cominuing Ectucation in Nursing A Mtodel and Mecham.sm. (Interim Executive Committee for the ANA Council on Continuing Education approved by Commission of Nursing Education) ANA. Kansas City. 1974.

6. ANA CE Requirements Definite for RNs in Fourteen Siates. Americion Jinurnal of Nursing. June 1980. pp. 1040, 1062, 1072

ANA Mandator: Compinuing Education: The Legislatwe State of the Art, A Revource Paper. American Nurses Association. Kansas City. May 1978.

\$. ANA Manual on Acrreditation of Cominuing FeduANA Manual on Actreditation of Cominuing Fidu-

9. ANA (Study Committee Credentialing in Nursing The Studs of Credentialing in Nursing: A New Approach Vol. I and II. American Nurses Association Kunsas City. January 1979

10. Buys. Conna As I was Saying. C.E. Fucus. Pacific Palisades, CA Vol. 2, No. 6. November December 1979 p. 2.

Fdior. CE Roundup. Nursing Careers. June 1980. p. 14

2. Del Beuno. Dorothy. Competency Based Fducation Vurs' Eslucour. May-June 1978.

13. Dodge, Gwen H. Legislators Look Askance at Mandacory CE AOR Y Journal May 1980 Vol 31 No 6

14. Hochman, Gloria. Continuing Educatıon. How Can You Make the Most Of 11? Vursing 78. December 1978 pp. $81-89$

Houle. Cyril O. Contimuing Leparning in the Professiom Iossey-Bass San Francisco. 1980

Kelly, Lucie Young. Dimensioms of Professional Nursing. Macmillan. New York. 198I. 4th Ed. pr. 648-651.

Levine, Myra E. Does Continuing Education Improve Nursing Practice? Journal of the American Hospital As sociarion. Vol. 52. November 1978. pp. 138-140.

8. Magner. Monica. Developing and Evaluating Inservice Programs. Supervisur Vurse. March 1978. pp. 10-11.

9. VACOG Fact Shed YAACOG Acereditation by the American Viurses Assuciation vational Accreditation Bmard. NAACOG Department Education. Chicago Bourd. NAA

20. Natienal Health Invurance Repurt Resistance to NurseMidwives Growing. Vol. 10. No. 26. December 26, 1980 pp. 1.2 .

21. Veale. Margo C. What's Happening with Mandatory CE" Mandatory CE The Stalus Today. Occuplotumel Health Nursing. Pacific Palisades. CA. November 1980 pp. 22-24.

22. Nurses Association American College Obstetrics and Gynecology Fat Sheet: WAACOG Accreditation hy the Amert Bellegrino Edmund D. Coninuing Educain in the Pellegrina. Edmund D. Continuing Education in the Health Professions. American Journal of Pharma ceumal Echuration. Vol. 13. December 1969

24. Pickard. Myrna R.: Burns. Nancy. Continuing Education for Rural Hospital Nurses Aursing Ouloroh June 1979. pp. $4|6-4| 9$.

25. Popiel. Elda S Approval Mechanism for Continuing Fducation In Nursing. CE Focus. Pacific Palisades, CA Vol 2. No. 6. November December 1979. pp. 6-7,9

26. Popiel. Elda S. Nursing und the Prusess of Comninume Filucution. Mos by St. Louis. 1977. 2nd Ed

Salmond, Susan W. Inservice and Patient Education Superviser Niurse. May 1978. pp. 95-101. 